\title{
Developing communication and thinking skills in English as a Foreign Language Education undergraduate students: a proposal for a syllabus model
}

\author{
Violeta Delgado-Crespo \\ Universidad de Zaragoza
}

\section{Vicky Gil}

Universidad de Zaragoza

\section{Pilar Mur-Dueñas}

Universidad de Zaragoza

\section{Silvia Pellicer-Ortín}

Universidad de Zaragoza

Special

Issue

- VI -

Language

Teaching

Research from a Global Perspective

2020
ONOMÁZEIN | Special Issue VI - Language Teaching Research from a Global Perspective: 104-125 DOI: 10.7764/onomazein.ne6.06

ISSN: 0718-5758

\section{(C) $\underset{\mathrm{BY}}{\ominus}$}

Violeta Delgado-Crespo: Departamento de Filología Inglesa y Alemana, Universidad de Zaragoza | E-mail:violedel@unizar.es

Vicky Gil: Departamento de Filología Inglesa y Alemana, Universidad de Zaragoza | E-mail:vickygil@unizar.es Pilar Mur-Dueñas: Departamento de Filología Inglesa y Alemana, Universidad de Zaragoza

| E-mail:pmur@unizar.es

Silvia Pellicer-Ortín : Departamento de Filología Inglesa y Alemana, Universidad de Zaragoza

| E-mail: spellice@unizar.es 


\section{Abstract}

It is our aim to share a proposal for a new syllabus model and learner-centered methodology for English as a Foreign Language students in the Degree in Teaching in Primary Education at the Universidad de Zaragoza (Spain), presenting the theoretical tenets and analyzing samples of resources and materials that have been designed. In a context of great diversity of levels and learning profiles in the abovementioned educational setting, it is no longer valid to conceive this part of teacher training only in terms of language proficiency, but rather it is necessary to equip students with learning to learn tools and metacognitive strategies as well as materials and resources purposefully designed bearing in mind their context, professional interests and linguistic needs. As a result, throughout the three 6 ECTS courses in the Degree (English in Primary Education I, II and III, for 1st, 2nd and 4th year students respectively) we seek to implement active methodologies and make use of a variety of resources following Communicative Language Teaching and Task-based Instruction principles, such as the following: (i) Deep Learning (Clark, 2009a, 2009b) and Scaffolded, Visible Thinking (Ritchhart, Church, and Morrison, 2011); (ii) Cooperative Learning (Kagan and Kagan, 1994); (iii) ICTS and EdTech; (iv) reflective learning, promoting self-assessment and peer-assessment, and (v) Project Based Learning (BIE, 2003). Overall, the teaching proposal designed has enabled us to partially respond to heterogeneity in our large classes and make our students' learning of a language relevant and meaningful.

Keywords: English as a Foreign Language; Communicative Language Teaching; Task Based Instruction; Content Enhanced Language Teaching; learning; Primary Education. 


\section{Introduction and justification}

In this article we present and analyze a teaching proposal that seeks to meet the challenge of teaching English as a Foreign Language (EFL) to students in the Degree in Teaching in Primary Education at the Universidad de Zaragoza (Spain). It is our contention that, in this context, designing instruction from the perspective of General English, aiming only towards standardized testing or certification, could be limiting, as it does not respond to all of the needs of future Primary teachers. We have found a significant diversity in our large class groups in terms of competence level and learning profiles. On the one hand there are students who may never reach the proficiency target levels due to the short span of time of instruction and their entry levels. On the other hand, some may have already acquired it in their earlier schooling. Their learning backgrounds are also varied in terms of their profiles and previous experiences as learners.

It is our contention that attending to this diversity requires a framework with new parameters other than traditional certification preparation or standardization, a framework that "makes sense in terms of current pedagogical and theoretical knowledge" (Kumaravadivelu, 1992: 41). These traditional parameters may translate into specific methodological practices which very often imply prioritizing a conception of the $\mathrm{FL}$ as a system, rather than focusing on learners and their learning processes, or even on the learning of a $\mathrm{FL}$. These practices constitute our concern in this particular context, since many of our future Primary teachers may receive certification for a B2 competence level at some point, outside of our training, allowing them to teach Content and Language Integrated (CLIL) lessons in any of the numerous schools with bilingual programs. As a result, those who do not take the courses in the speciality in ELT will be teaching in English without any initial professional knowledge and skills for teaching and learning a $\mathrm{FL}$.

It is from this perspective that we have developed a proposal for teaching that we hope may lead to more effective and adaptive learning within our context. In the following pages, the specific objectives of this article will be put forward. This will be followed by a brief theoretical discussion of the main frameworks that support our proposal. Next, the specific academic context will be described in more detail. After this, we will focus on the didactic proposal itself. Finally, we will draw relevant conclusions and discuss some implications and avenues for further improvements.

\section{Objectives}

The aim of this paper is to identify and exemplify an EFL syllabus model for Education undergraduate students leading to the development of their communicative skills which, while drawing on the common basis of the CEFR (2001), seeks to achieve more than General English and certification. Rather, it tries to respond to the specific linguistic and didactic needs of 
future Primary teachers respecting their heterogeneity, making language learning relevant and meaningful in this specific context.

\section{Theoretical framework}

To this end, we can turn to Kumaravadivelu's operating principles for postmethod pedagogy (2006). Kumaravadivelu points to three principles to shape a framework able to respond to the demands of context, which are particularity, practicality and possibility. In a specific instructional context, we can be guided by the idea of particularity, that is, we need to develop a context sensitive pedagogy that takes into account the established curriculum and our students' professional needs and interests. We also need to bear in mind practicality, that is, theorizing from practice and practicing what we theorize. In teacher education this can be translated as the need to design a type of instruction that integrates a reflective approach to learning, a focus on learning processes and learners themselves. Finally, we also need to be aware of possibility, that is, the power of teaching for individual or social transformation. In other words, we need to design a type of instruction that has the potential to promote actual changes in the individual as a future professional and, by extension, in society. In our view, this framework may effectively transcend the limitations of the concept of language learning in teacher education as competence level development.

A framework that relies on context and learner needs and interests in EFL is that of Communicative Language Teaching (CLT), in general, and the Task-based approach (Estaire and Zanón, 1994; Willis, 1996; Willis and Willis, 2007; Ellis, 2003), in particular. While CLT prioritizes interaction and the creation of opportunities to use the language for a purpose and in a given context, Task-based Instruction (TBI) has a psycholinguistic orientation that was not developed in CLT, as Kumaravadivelu (2006) contends. Together with the functional view of language of CLT, this orientation allows us to pay attention to cognitive processes and the "development of understanding, not just the passive reception of 'knowledge' or the acquisition of specific skills" (Finney, 2002: 73). As we shall see, tasks, as a way to integrate metacognition, become the backbone of the proposal presented here.

In addition, postmethod pedagogy gives us the flexibility to allow for a different focus and to integrate other approaches. Particularity can be translated into instructional design through what Ball (2016) calls Content Enhanced Language Teaching (CELT). In CELT, content plays a key role for language learning but is only assessed in an instrumental way, in as far as it is expressed and communicated through language. From this perspective, when content is specific, as opposed to the content of General English courses, it can receive more prominence. It becomes more powerful than in average target level instruction for Education undergraduate students, as it is more relevant for the development of their professional linguistic skills and knowledge. 
In turn, a more powerful content allows us to pay attention to thinking and learning processes, that is, to cognition and metacognition. This is how we interpret Kumaravadivelu's practicality. Making learning and thinking deep and visible (Clark, 2009a, 2009b; Ritchhart, Church, and Morrison, 2011) focuses on the students' learning processes through the use of tools such as think charts, organizers, and thinking routines. Charts and organizers may allow students to engage both with content and language with a certain degree of complexity, activating their higher order thinking skills. This is more demanding from a cognitive perspective than the mechanical completion of traditional exercises organized around "general interest topics", but also more formative and more rewarding. Through reflection, students take responsibility for their individual learning. They are required to identify their weak and strong points; adopt a teacher's perspective as they assess their own work or that of their classmates; and be systematic when approaching tasks, in order to identify task objectives and thus be more aware of what is expected of them. Finally, reflective learning also requires them to personally engage with the tasks by expressing their feelings or opinions so that knowledge may become significant to them.

If we focus on possibility, on how our teaching and the learning it promotes can transform the individual and society, we can identify Cooperative Learning (Kagan and Kagan, 1994) as a valuable methodology in teacher education, together with Project-based Learning (Buck Institute of Education, 2003), as the types of instructional sequences which both require and facilitate effective interaction. Cooperative learning makes students work together in teams to accomplish shared goals, through the necessity of positive interdependence. This requires the teacher to strengthen the feeling that individual success depends on collective success (Scott, 2006: 134). Cooperative learning highlights the notion that students learn most effectively while interacting with their peers because they verbalize their learning processes, making them visible and therefore more meaningful (Johnson and Johnson, 2010; Slavin, 1980). PBL as a learner-centered approach encourages students to build their own learning while interacting and cooperating with their classmates. PBL requires teachers to adopt the role of guide and facilitator of knowledge (Papandreou, 1994).

On the other hand, a learner-centered approach requires fostering motivation and learner autonomy. For this end, ICTs and EdTech prove to be very useful, since they arouse and sustain curiosity and attention, increasing students' interest and involvement in the tasks (two key components of motivation in the EFL classroom (Dörnyei, 1994; Pearse-Romera y Ruiz-Cecilia, 2019), as well as promote autonomy to continue learning outside the classroom. A learner-centered approach also requires reflection and self-assessment. According to Iannou-Georgiou and Pavlou (2003: 10), self-assessment "promotes invaluable learning skills such as monitoring one's own progress, reflecting on one's abilities and learning styles, and setting personal goals". Although some disadvantages have to be considered, such as subjectivity and the difficulties in finding one's own mistakes, there are noteworthy benefits, namely "direct involvement of students in their own destiny, the encouragement of autonomy, and increased motivation because of their engagement" (Brown, 2001: 145). 


\section{Academic context}

\subsection{Study programs}

In the curriculum of the Degree in Teaching in Primary Education of the University of Zaragoza (Spain), which was implemented for the first time in the academic year 2010-2011, there are only two 6 ECTS courses in EFL (English in Primary Education I, English in Primary Education II) and they are mandatory for all undergraduate students. It is not until the fourth and last academic year that we find five 6 ECTS courses on teaching and learning EFL at Primary level, one of them being another course in EFL (English in Primary Education III). However, being elective courses, only those students that choose the Speciality in English (Mención en Lengua Ing/esa) take them. Although in the curriculum of the Degree these two courses mentioned above are part of the module "Language Teaching and Learning", typically, mandatory instruction in EFL for the undergraduate Primary student has focused on General English and followed the perspective of competence level development in terms of the CEFR. Assessment, likewise, has been more focused on testing competence level than on testing the contents, skills and strategies in which undergraduate students are specifically instructed.

\subsection{Target students}

The proposal here described is aimed both at the students taking the mandatory courses English in Primary Education I and II, as well as those taking the elective course English in Primary Education III. The mandatory courses are taught in four groups of around sixty students. The elective course has only one group of around forty-five students. Being a specialty course, in the latter we can observe less diversity in competence level.

\section{Proposal}

A flexible framework has allowed us to make each course different. Thus, in English in Primary Education I we make use of the four-skills model for the instructional design of the didactic materials, integrating some content specific language tasks (Ellis, 2003). This model seems to be aligned with our students' methodological expectations since, as Hedge (2000) contends, effective teaching and learning of a FL requires taking learner expectations into account. The syllabus model for this first year could be described as content enhanced (Ball, 2016). In addition, the course integrates thinking tools to make learner engagement with content more significant, an idea for which we found inspiration in Lane Clark's Deep Learning methodology for the content classroom (2009a, 2009b). In English in Primary Education II, specific content is also central to the design, but the course is organized around tasks: the learning units are task-based, rather than four-skill based. In these tasks, thinking about content and thinking about learning processes are fully integrated, the focus being on developing competences and demonstrating competence through students' performance. In English in Primary 
Education III, we have integrated a project as a central element in the syllabus. In this project, thinking tools and processes are also primary. As shall be discussed, the distinctive feature of its design is that it has the added potential of making a difference in the students' lives and in the lives of others, as Clark would put it (2009a).

As highlighted above, a key feature of our proposal seeks to respond to our students' professional needs and interests. In so doing, we have followed CLT principles (Brown, 2001, 2002), establishing clear contexts in which language is used for a given purpose. Likewise, the tasks designed are relevant and meaningful to Education students, the focus being first and foremost on making our students' develop their communicative competence. Let us focus on each of these features to describe and analyze the proposal made for each course.

\subsection{CLT principles, Task-based Instruction, and CELT}

Instructional design is grounded on CLT and TBI principles in order to give students opportunities to use the language for a purpose and in a given context, enabling them to develop their communicative language competence. What is more, we believe that this process of adjusting the activities and tasks to their likely professional needs through a CELT approach and grounding them on validated communicative principles should be taken by student teachers as a model of the type of lessons, materials, and resources they should be creating, adapting, designing, implementing, and evaluating in their future teaching careers.

When designing these language courses, we have planned both enabling or pedagogical tasks as well as communicative ones (Estaire and Zanón, 1994). Students are led in the units towards the successful completion of a final task in which they produce a clearly defined communicative output (Ellis, 2003). Thus, in the course English in Primary Education I, students are offered opportunities to complete simpler tasks, such as creating a leaflet for their ideal summer camp, designing a Google Form with comprehension questions on class materials, or developing an action plan for a healthy school.

In the course English in Primary Education II students can complete varied communicative activities, such as recording a video in which they carry out a scientific experiment following and explaining the different stages of the scientific method; creating an audio guide to their favourite European city; or building their own time capsule to be opened at the end of their degree (Figure 1). For each of these final outcomes, students complete enabling tasks, processing input such as content, ideas, and language, prior to completing their final task. For instance, in relation to the example in Figure 1 , they are given oral and written input on time capsules, how they work and what to put in them through specific written texts (e.g. Frequently Asked Questions) and oral texts (e.g. YouTube videos, a "Time Capsule" Peppa Pig episode), and are asked to complete reading and listening comprehension tasks. They also complete some activities on tenses and time expressions which they will need in order to write their letters to themselves in the future. Finally, they are guided in the process of writ- 
ing the accompanying letter, following the different stages of the writing process (i.e., generating ideas, focusing and structuring ideas, drafting, revising, editing, and publishing (Tribble, 1996; Hedge, 2005)). At the end of the unit, students should create their time capsules and bring them to class to be presented to their classmates in groups. The capsules will be opened when they finish their degrees in a scheduled session. As can be seen, authentic materials are used as a source of input, students work both individually (writing the letters and preparing their time capsules) and also collaboratively (as they present their capsules to each other and read their letters, giving their partners feedback) and the focus is on conveying their ideas.

\section{FIGURE 1}

Example of a communicative taskassigned to students in English Primary II Education. (Source: own elaboration)

\section{PREPARE YOUR TIME CAPSULE AND BE READY TO PRESENT IT IN CLASS}

- Build your own time capsule and bring it to class on Tuesday $10^{\text {th }}$ April.

- Describe what is inside, what you included in it (A letter or an audio message based on that letter must be included).

- Be ready to explain why you have chosen those items.

- Read your letter or play the audio of yourself reading the letter or sending a message to whoever opens the time capsule in the future.

- Your teacher will take the time capsules and keep them until you finish your degree (to be opened in June 2020).

In English in Primary Education III, further tasks are proposed which are related to students' professional career. They are asked to create and record their own Ted Talk on a topic that is relevant to their teacher training. Another task is to become youtubers and prepare their own review of a popular TV series, appropriately using descriptive language as well as persuasive language (to convince their audience to watch the TV series) (Figure 2).

\section{FIGURE 2}

Example of a communicative task assigned to students (“Creating your own Ted Talk”). (Source: own elaboration)

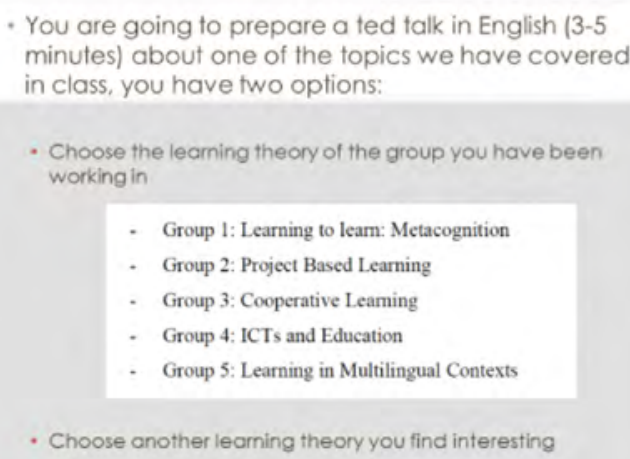

Become an expert in that theory (revise your readings and videos. check the ldeas you have shared with your classmates, look for other information....

You have to convince us that your learning theory is the greatest methodology to improve education of the present moment, malniy in Primary Education

Record your talk

Upload it on your blog with the fitle: MY TED TALK (and your name in brackels) by Oclober, 16.

The teachers will upload a list on Moodle with the pairs that will revise each other's taik

You will have to watch your classmate's talk

You will use the following rubric to give a mark to your classmate

You will upload the rubric on Moodle by Friday, October 20 
Again, students are led through pedagogical tasks to these final communicative tasks working on the content and the language, which are shared with their classmates after being revised and edited with the help of self-assessment and peer assessment tools (see section 5.3).

Following Ball (2016), we believe our lessons are a model of CELT. As can be seen in Table 1 , instruction is designed around topics that are meaningful to Education students and contribute to their professional development. Students are first exposed to input (both oral and written) and their attention is drawn to specific language functions and exponents which they will need in order to produce their final outcomes demonstrating their understanding of ideas in these specific outputs. Students watch several videos and/or read printed and digital texts on topics of their likely interests and carry out specific tasks that contribute to their development of the macro- and microreading and listening skills, such as listening and reading for general ideas, for details or specific information, and making predictions and inferences. Besides, attention is paid to the content ideas, since these are necessary to create their final products. They are pushed to apply that knowledge for the successful completion of their outcomes.

\section{TABLE 1}

Main topics chosen for the EFL courses in the Degree in Primary Education. (Source: own elaboration)

\begin{tabular}{|c|c|c|}
\hline $\begin{array}{l}\text { ENGLISH IN PRIMARY } \\
\text { EDUCATION I }\end{array}$ & $\begin{array}{l}\text { ENGLISH IN PRIMARY } \\
\text { EDUCATION II }\end{array}$ & $\begin{array}{l}\text { ENGLISH IN PRIMARY } \\
\text { EDUCATION III }\end{array}$ \\
\hline $\begin{array}{l}\text { Fairy tales and storybooks } \\
\text { Visual literacy } \\
\text { Action plans for healthy schools } \\
\text { Outdoor play } \\
\text { Traditional games } \\
\text { Consuming kids }\end{array}$ & $\begin{array}{l}\text { Bilingual education } \\
\text { CLIL } \\
\text { Natural and social sciences } \\
\text { Physical Education } \\
\text { Arts and Crafts }\end{array}$ & $\begin{array}{l}\text { Becoming an English teacher } \\
\text { Children around the world } \\
\text { Education in developing countries } \\
\text { Storytelling }\end{array}$ \\
\hline
\end{tabular}

This communicative view of language comes together with a specific view of the nature of learning in general, and of language learning in particular, which focuses on thinking and learning processes and the conditions for these processes to be activated. As has been pointed out, this view of learning led us to integrate a variety of approaches and techniques, namely, the use of ICTs, visible and reflective learning, cooperative and collaborative learning, and Project Based Learning. We will discuss them in the following sections.

\subsection{The use of ICTs}

The positive effect of the use of ICTs in students' learning of a second language has been shown by previous research (e.g., Azmi, 2017; Lopes and Ruiz-Cecilia, 2017). When they are used in a relevant, significant way and from a learner-centered perspective, they become a catalyst to improve teaching and enhance learning in the university classroom, as Yazon, 
Mayer-Smith, and Redfield (2002: 268) contend. According to Richards and Rodgers (2014), ICTs encourage a more active learning by facilitating learner engagement and the development of learner autonomy. They can also contribute to the development of the learners' communicative competence by increasing motivation and opportunities for interaction and meaningful language use, as well as to focus on particular skills, and by supporting learning outside the classroom (Richards and Rodgers, 2014). In addition, a relevant ICT use will become a model of good practice for student teachers.

With this in mind, we have fostered the meaningful use of ICTs, for example, through G Suite for Education and Moodle (both available at the University of Zaragoza). Students have been asked to complete and design Forms, and use Drive and Docs when completing tasks collaboratively. The use of ICTs has been most successful in providing support to those students who needed extra guidance or practice both inside and outside the classroom boosting autonomous learning and maximising targeted outcomes (Azmi, 2017). In this respect, Moodle has been used not only as a repository of teaching materials but as an interactive tool to create especially designed quizzes, assignments, and questionnaires. Students were given opportunities to complete reading, listening, and Use of English quizzes on the specific topics covered in the different units. These quizzes were used as formative assessment, allowing the teacher to make decisions on what particular aspects needed to be further practiced individually.

A number of other apps, such as Socrative, Kahoot, and Plickers, have also been used in class and they have proven to be highly motivating learning tools. Socrative has allowed students to complete exit tickets, making them reflect on their learning in class, and providing opportunities for noticing and restructuring language as they engage with the production of those written texts (Pellettieri, 2000, in Richards and Rodgers, 2014: 341), whereas Kahoot and Plickers have fostered game-based learning. With the purpose of encouraging learner engagement, the classroom management app Class Dojo has been employed in English in Primary Education I so that students could keep track of their completion of tasks. This shows that the teachers' knowledge about classroom teaching and materials selection, combined with knowledge of Computer Assisted Language Learning (CALL) (Chapelle, 2003), fostered our students' L2 learning at the same time as it constitutes an example of good teaching practice.

Moreover, ICTs are present in our didactic proposal through digital genres. Students are asked to read digital texts such as blog entries, or FAQs on the Internet, and complete their own digital texts, creating, for example, their student blogs in English in Primary Education III. Along with this, Computer-Mediated Communication (CMC), especially Asynchronous CMC, has been introduced in the classroom providing students with realistic contexts for the use of the target language through different channels (Blake, 2008; Richards and Rodgers, 2014). For instance, Symbaloo was used to share and make the students' output available to other classmates. Finally, a number of other resources such as QR codes, Canva, EdPuzzle, or IziTravel have been used for the completion of tasks (e.g. recording their Ted Talk, or creating their audio guide). 


\subsection{Making learning visible}

Following the research and practical proposals of Project Zero Harvard, we integrate scaffolded thinking in our tasks, through thinking routines. Routines such as See-Think-Wonder or Think-Puzzle-Explore (Ritchhart, Church, and Morrison 2011) help learners actively engage with content, making the language to deal with it required and relevant. At the same time, routines give structure to thinking and their language use. For instance, we use the See-ThinkWonder routine in English in Primary Education I to support oral production (Figure 3). This is a very powerful tool to help our first year undergraduate students to generate ideas and structure their oral production.

\section{FIGURE 3}

Example of a routine used in English for Primary Education I. (Source: own elaboration)

\begin{tabular}{|c|c|c|}
\hline SEE & THINK & WONDER \\
\hline (Describe) & (Interpret) & (Imagine) \\
\hline $\begin{array}{l}\text { I can see... } \\
\text { There is/are... } \\
\text { The picture shows... }\end{array}$ & $\begin{array}{l}\text { I think that... } \\
\text { It seems (likely) that... } \\
\text { I would say that... } \\
\text { They/it could/may be... } \\
\text { I suppose... } \\
\text { It looks as if... } \\
\text { Perhaps/maybe... } \\
\text { (She) seem(s) to be ... } \\
\text { You can tell that... } \\
\text { I would imagine... }\end{array}$ & $\begin{array}{l}\text { I wonder if... } \\
\text { (Think about the past, the future or consequences, } \\
\text { problems, etc.). That is, talk about the topic the images } \\
\text { suggest or bring to your mind / make you think of, etc. } \\
\text { The image suggests /makes me think of } \\
\text { / reminds me of / brings to mind... } \\
\text { Here you could also establish a connection } \\
\text { with your own experience of the topic. } \\
\text { You could also be asked to think of what } \\
\text { you could do as a teacher to solve the } \\
\text { problem or situation the picture shows. }\end{array}$ \\
\hline
\end{tabular}

We provide students with images connected to the specific topics that we deal with in the course and we teach them how to go through this routine to talk about them. Following this routine, first, the students describe a selected image, then they interpret it, and finally they establish connections with it, that is, they talk about what the particular image suggests to them. For all these functions we provide them with relevant language to scaffold both their thinking and their production in the form of cheat sheets.

Together with this type of routines we make regular use of visual organizers to complete a great diversity of tasks (see Figure 4). Although visual organizers are not new, due to the increasing focus on the necessity to develop organizational and thinking skills in language classrooms, visual tools have become more popular in the last few years. This is also due to the growing interest in CLIL, CELT, and LEST (Language Enhanced Subject Teaching) (Ball and Lindsay, 2012) approaches to FL teaching, in which organizers are used to help learners to connect knowledge and ideas; understand, recall, select, transfer, and categorise information; produce oral and written language; and think creatively (Bentley, 2010; Ball and Lindsay, 
2012). The type of visual organizer can be selected according to the completion needs of the learners. In our case, tasks may be more language-oriented (focusing on some specific skill or linguistic content), but tools such as Carousel Think Cards (Nessel and Baltas, 2006), Learning and Immersion Centers (Clark, 2009a) are also used for research tasks in which students have to work collaboratively to find, organize, register, and share the information collected in diverse sources of input.

\section{FIGURE 4}

Example of a think chart in English in Primary Education III: Organizing information of some texts and a video on the situation of children in need around the world. (Source: adapted from Clark, 2009a)

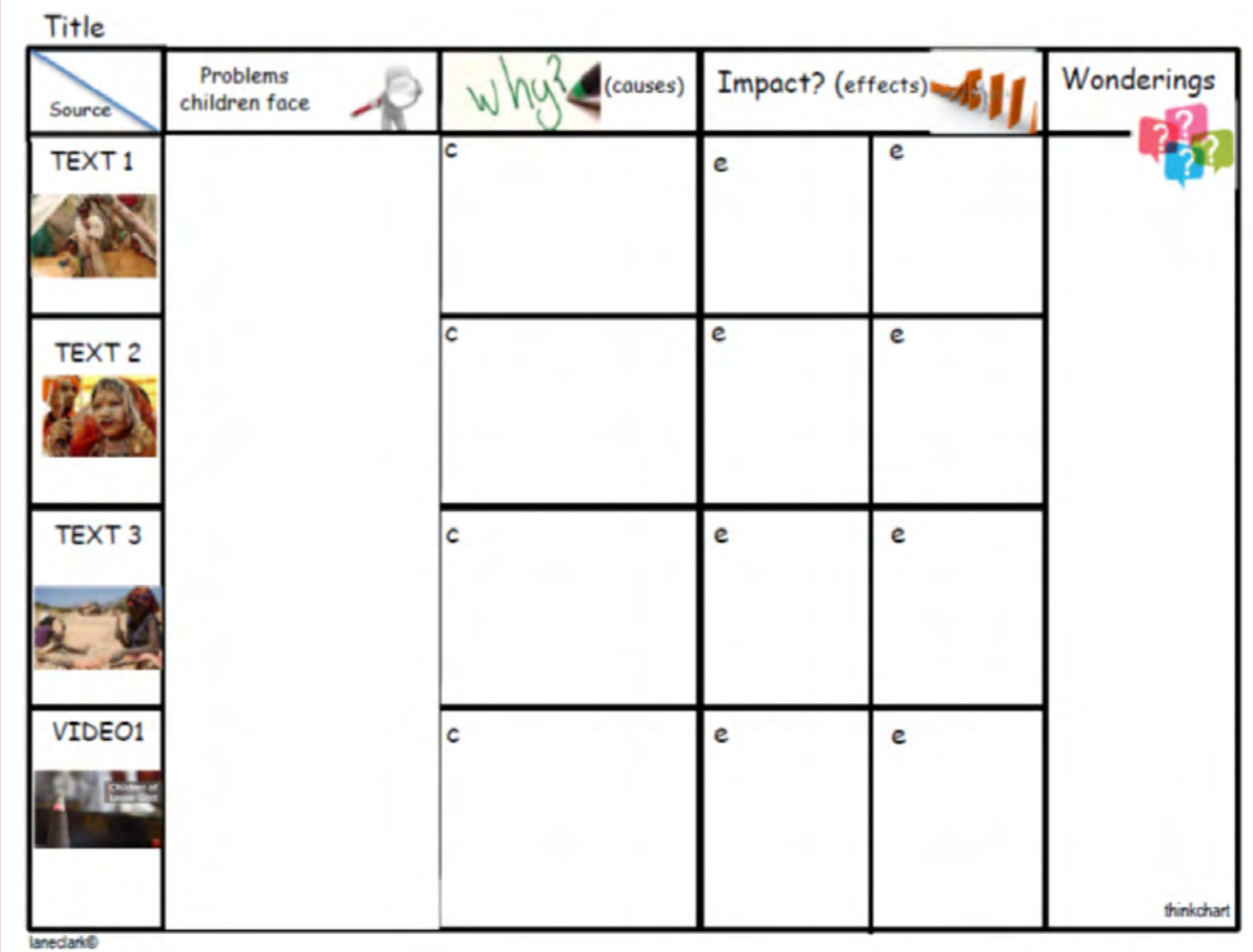

As Figures 5.1 and 5.2 below show, Carousel Think Cards explore and activate the students' previous knowledge before starting a task, a unit or a project. Furthermore, these organizers guide the students' thinking processes and thus develop their critical and metacognitive skills. According to Clark (2009b), this is essential to develop deep learning processes and the learners' ability to think and be aware of the development of their thinking processes. To put it briefly, all these resources enable our learners to use language for thinking and to promote purposeful as well as meaningful communication. 


\section{FIGURE 5.1}

Carousel Thinking used in English in Primary Education II. (Source: own elaboration)

\section{CAROUSEL THINKING}

1. Get in groups of $4-5$.

2. Your group will be assigned a coloured marker.

3. Group 1: blue; Group 2: red; Group 3: green; Group 4: purple; Group 5: orange

4. You will be assigned a question related to the topic of critical thinking. In your groups, discuss the specific question noted on the piece of paper and then write down everything you know.

5. After 5 minutes, each group should rotate to the next station where you will read the new question and what others have written about it, discuss it with your group, and add new information. You can also write questions about things that other groups wrote (existing answers/notes about the topic/question).

6. Continue this process until each group is back to their original station.

\section{FIGURE 5.2}

"Carousel Think Cards: Students' Output" used in English in Primary Education II. (Source: own elaboration)
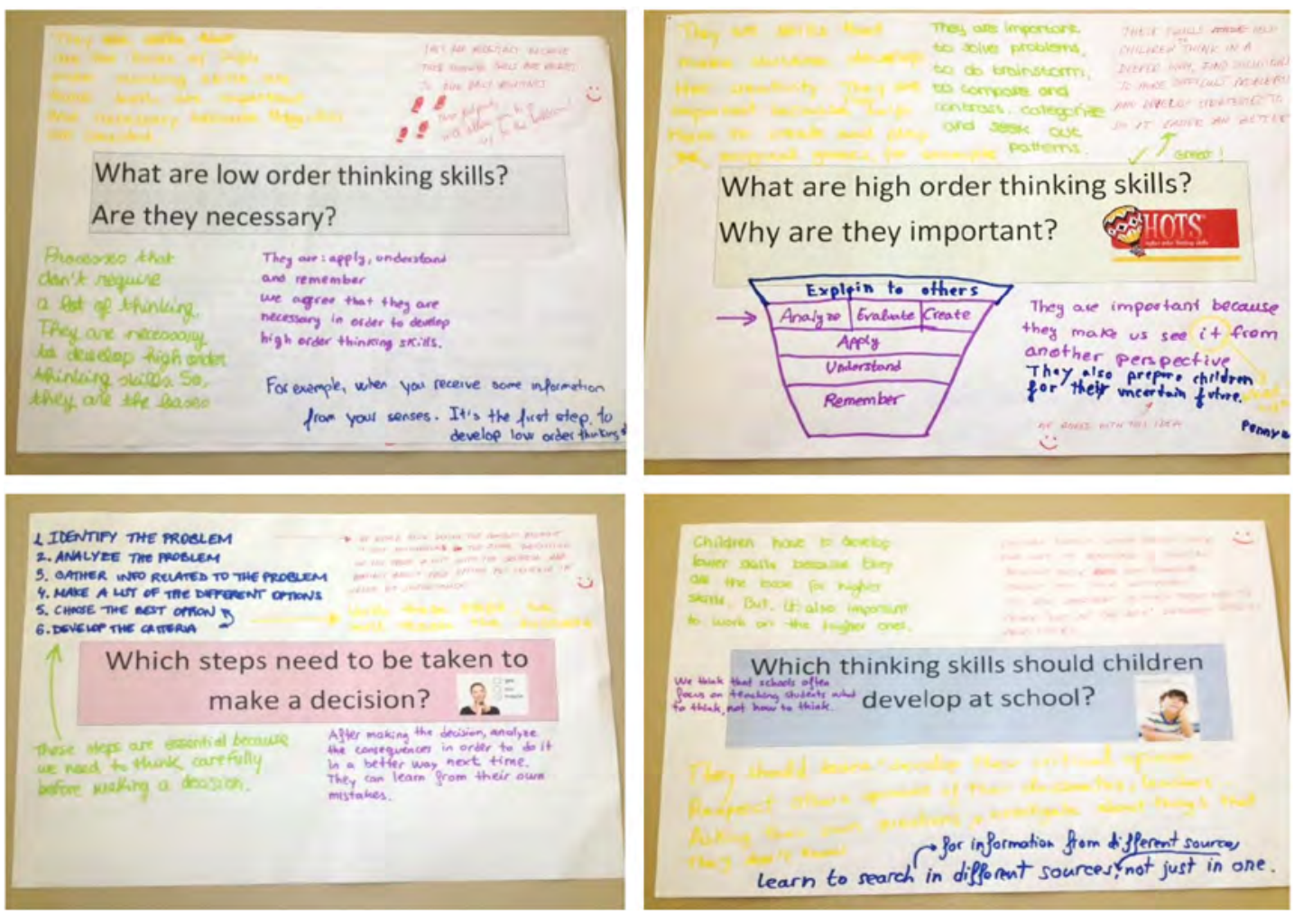

Another way of making learning visible is through self- and peer assessment. Some of the most common tools to introduce self- and peer assessment in our didactic proposal are rubrics (Table 2), checklists (Figure 6), exit tickets, one-minute papers, portfolios, and learning journals. 


\section{TABLE 2}

Peer assessment rubric for the Ted Talk in English in Primary Education III. (Source: own elaboration)

\begin{tabular}{|c|c|c|c|c|}
\hline & 1 POOR & 2 ACCEPTABLE & 3 GOOD & 4 VERY GOOD \\
\hline Content & $\begin{array}{l}\text { The talk does not } \\
\text { offer very relevant } \\
\text { knowledge on } \\
\text { the given topic. }\end{array}$ & $\begin{array}{l}\text { The talk offers } \\
\text { some general ideas } \\
\text { on a given topic. }\end{array}$ & $\begin{array}{l}\text { The talk is } \\
\text { informative and } \\
\text { shows some } \\
\text { research on } \\
\text { the topic. }\end{array}$ & $\begin{array}{l}\text { The talk is } \\
\text { informative, based } \\
\text { on some previous } \\
\text { research, and offers } \\
\text { a review of some } \\
\text { learning theories. }\end{array}$ \\
\hline Structure & $\begin{array}{l}\text { The ideas are not } \\
\text { clearly and logically } \\
\text { structured. } \\
\text { None of these } \\
\text { elements is present. }\end{array}$ & $\begin{array}{l}\text { The text is } \\
\text { difficult to follow } \\
\text { due to the lack } \\
\text { of discourse } \\
\text { markers. Many of } \\
\text { these elements } \\
\text { are missing. }\end{array}$ & $\begin{array}{l}\text { There is a logical } \\
\text { connection of ideas. } \\
\text { Some of the } \\
\text { following elements } \\
\text { cannot be easily } \\
\text { distinguished: } \\
\text { a clear introduction, } \\
\text { main arguments, } \\
\text { examples and } \\
\text { concluding } \\
\text { thoughts sections. }\end{array}$ & $\begin{array}{l}\text { There is a clear and } \\
\text { logical connection } \\
\text { of the ideas thanks } \\
\text { to the use of } \\
\text { discourse markers. } \\
\text { There is a clear } \\
\text { introduction, } \\
\text { main arguments, } \\
\text { examples and } \\
\text { conclusion } \\
\text { sections. }\end{array}$ \\
\hline Vocabulary & $\begin{array}{l}\text { The student } \\
\text { frequently uses } \\
\text { phrasal verbs and } \\
\text { colloquial language. } \\
\text { There is neither } \\
\text { nominalization nor } \\
\text { specific vocabulary. }\end{array}$ & $\begin{array}{l}\text { The student } \\
\text { sometimes uses } \\
\text { phrasal verbs } \\
\text { and colloquial } \\
\text { language. There is } \\
\text { no nominalization } \\
\text { or specific } \\
\text { vocabulary. }\end{array}$ & $\begin{array}{l}\text { The student } \\
\text { sometimes uses } \\
\text { one-word verbs, } \\
\text { nominalization, } \\
\text { formal words and } \\
\text { specific vocabulary. }\end{array}$ & $\begin{array}{l}\text { The student } \\
\text { always uses } \\
\text { one-word verbs, } \\
\text { nominalization, } \\
\text { formal words and } \\
\text { specific vocabulary. }\end{array}$ \\
\hline Grammar & $\begin{array}{l}\text { There is no use } \\
\text { of passive voice, } \\
\text { impersonal } \\
\text { structures, hedges } \\
\text { or reporting verbs. } \\
\text { Mistakes impede } \\
\text { intelligibility. }\end{array}$ & $\begin{array}{l}\text { There is a lack } \\
\text { of passive voice, } \\
\text { impersonal } \\
\text { structures, hedges } \\
\text { and reporting } \\
\text { verbs. It contains } \\
\text { a lot of mistakes. }\end{array}$ & $\begin{array}{l}\text { The student } \\
\text { sometimes uses } \\
\text { passive voice, } \\
\text { impersonal } \\
\text { structures, hedges } \\
\text { and reporting } \\
\text { verbs (sometimes } \\
\text { with mistakes). }\end{array}$ & $\begin{array}{l}\text { There is abundant } \\
\text { and correct use } \\
\text { of passive voice, } \\
\text { impersonal } \\
\text { structures, hedges } \\
\text { and reporting verbs. }\end{array}$ \\
\hline Pronunciation & $\begin{array}{l}\text { There are many } \\
\text { relevant mistakes } \\
\text { in pronunciation } \\
\text { and stress patterns. }\end{array}$ & $\begin{array}{l}\text { The pronunciation } \\
\text { is not clear and } \\
\text { there are some } \\
\text { mistakes. }\end{array}$ & $\begin{array}{l}\text { The student tends } \\
\text { to pronounce } \\
\text { clearly. }\end{array}$ & $\begin{array}{l}\text { The student usually } \\
\text { pronounces clearly } \\
\text { and correctly, } \\
\text { making use of } \\
\text { changes in stress } \\
\text { patterns to attract } \\
\text { the audience's } \\
\text { attention. }\end{array}$ \\
\hline Performance & $\begin{array}{l}\text { The student does } \\
\text { not make use } \\
\text { of persuasive } \\
\text { strategies and } \\
\text { body language. }\end{array}$ & $\begin{array}{l}\text { The student makes } \\
\text { use of persuasive } \\
\text { strategies or } \\
\text { body language. }\end{array}$ & $\begin{array}{l}\text { The student makes } \\
\text { use of persuasive } \\
\text { strategies and } \\
\text { body language. }\end{array}$ & $\begin{array}{l}\text { The student } \\
\text { makes good use } \\
\text { of persuasive } \\
\text { strategies and } \\
\text { body language. }\end{array}$ \\
\hline
\end{tabular}


Other tools, like learning paths and questionnaires, are also used to promote self-regulated learning and increase the learners' feeling of self-efficacy (Dörnyei, 1994). These tools demonstrate to learners that reflection is a learning tool and a powerful mechanism for change. Moreover, it is also a model of good practice for future teachers (Hedge, 2000). As Scrivener contends, "the first important step towards becoming a better teacher involves an increased awareness about what you do now and an openness to the possibility of change" (2005: 385). When we introduce activities that promote students' reflection on teaching practices, we are contributing to the further development of their metacognitive and, thus, professional skills. For instance, Table 3 shows that students can reflect on their feelings, learning outcomes, and the implications of what they have learnt after having carried out a specific task. Figure 7 corresponds to a questionnaire used in English in Primary Education II in order to help students not only to reflect on the development of their linguistic skills but also to become familiarized with specific vocabulary from the field of $E F L$, which is necessary, for example, for teaching content through English (such as Arts, Natural Science, Social Science, or PE).

\section{TABLE 3}

Post-task think chart for English in Primary Education I. (Source: own elaboration)

\section{DEBRIEFING THINK CHART}

1. What happened?

Indicate the steps that were followed to carry out the activities.

2. What did you learn?

Write down what the most relevant learning outcomes in the lesson were, and to what degree you feel you achieved them.

3. How did you feel?

Note down your feelings at the beginning, during and the end of the lesson.

4. What if?

Try to think about what would have happened if the activity had been conducted in a different way (methodology) or with another set of instructions.

5. How does this relate to the real world?

Reflect on the extent to which the activities you carried out may be useful to you as a language learner and/or as a future primary (English) teacher.

6. What next?

How can you link what you learnt in that lesson with your future teaching career? 


\section{FIGURE 6}

Student peer assessment checklist for audio guide in English in Primary Education II. (Source: own elaboration)

\section{CREATE AN AUDIO GUIDE}

CHECKLIST

Name of the crealors of the audio guide: Your namc:

\begin{tabular}{|l|l|l|l|l|}
\hline Does the audio guide & Yes & No & Parlially & Comrments \\
\hline 1. provide general information about the city? & & & & \\
\hline 2. give the exact location of each monument/site? & & & & \\
\hline $\begin{array}{l}\text { 3. inform about the hisrory of each of the } \\
\text { monumt:nt/sitc? }\end{array}$ & & & & \\
\hline $\begin{array}{l}\text { 4. give some (interestingl characteristics of the } \\
\text { monument/sitcs? }\end{array}$ & & & & \\
\hline $\begin{array}{l}\text { 5. inform about the main services, opening hours etc } \\
\text { of the monument/sile? }\end{array}$ & & & & \\
\hline $\begin{array}{l}\text { 6. connect the monument/guide with the one before } \\
\text { and/or the one after? (creating a proper route) }\end{array}$ & & & & \\
\hline Do the speakers in the audio guide & & & & \\
\hline 7. usc the lariguage: accuratc:ly? & & & & \\
\hline $\begin{array}{l}\text { 8. adapt the language to the audience (e.g. families, } \\
\text { young people, kids)? }\end{array}$ & & & \\
\hline $\begin{array}{l}\text { 9. use intelligible pronunciation? Use intonation } \\
\text { appropriately? }\end{array}$ & & & & \\
\hline
\end{tabular}

\section{FIGURE 7}

Questionnaire completed at the end of Unit 1 in English in Primary Education II. (Source: own elaboration)

\section{REFLECTION ON PRACTICE AND LEARNING - UNIT I}

1. Which macro-skills have you practised? Tick as appropriate.

RECEPTIVE MACRO-SKILLS

Reading

Listening
PRODUCTIVE MACRO-SKILLS

speaking

Writing

2. Think of the writing activity.

What type of written text was analyzed and practiced?

Was the context clear? Who writes to whom? Why/what for?

How did you generate ideas?

How did you focus and structure those ideas?

How many versions did you write?

What improvements did you make from the first (draft) to the last version (product)?

What type of information was included in the checklist? Did it focus on... content? structure? appropriateness? form/correctness?

3. Think of the speaking activity.

Which speech event was practiced?

Was the context clear? Who talked to whom? Why/what for? When/where? 
To sum up, the inclusion of this reflexive dimension in our courses is expected to foster our students' deeper learning, as they can establish connections between the techniques and materials they are using in class and their pedagogical implications for their own learning, and also for their future teaching. This will further increase their motivation, since they may find a positive model to improve their future teaching practice in the way that language use is promoted and in the pedagogical resources that are used.

\subsection{Cooperative learning and PBL}

We understand that, since our EFL courses need to prepare our future teachers to work in a team, share opinions with other colleagues, and make use of their social skills in heterogeneous environments, we have to include cooperative principles as part of this training. As can be seen from the tasks and materials shown so far, group work is promoted as well as meaningful cooperation in order to successfully complete the tasks, encouraging dialogue and group discussions, which may potentially lead to the development of a wide range of social skills such as conflict resolution, decision-making, active listening or empathy. When designing these activities, the five principles of cooperative learning fostered by Johnson and Johnson (2010) have been considered: i) positive interdependence; ii) face-to-face promotive interaction; iii) individual and group accountability; iv) interpersonal and small group skills; and $v$ ) group processing.

In English in Primary Education III these principles have been applied to tasks developed within a project designed to help children at an actual nursery school in India by creating storybooks for them. The project was carried out in the final unit: "Children Around the World". Together with the previous principles, it followed many of Clark's tenets (2009a, 2009b). Her methodology is aimed at developing a wide range of tools to foster deep thinking and learning (the think!nQ learning model, thinking frameworks, learning and immersion centers, and a great variety of visual organizers, think charts, and tasks). Clark's conception of teaching and learning has been applied when working with projects whose aim is to make a change in the life of others (Clark, 2009a) and to lead students to reflect on the so what of what they learn and its application to their own lives, their communities and the lives of others, echoing the principles of service-learning (Eyler and Giles, 1999).

When designing the cooperative teams to create the stories, we followed Kagan's ideas (1994: 35-38). In Kagan's view, the ideal group should be made of four heterogeneous individuals with different levels: Iow level, high level, medium-low level, medium-high level. Moreover, the five key principles of cooperative learning mentioned before were applied, with the exception of individual and group accountability, which was more difficult to measure, as we did not assign specific roles to group members. In addition, after some brainstorming activities, and in line with Clark's methodology, the immersion learning stage was organized into five main learning centers that students had to analyze, following the corresponding task cards, in order to complete each think chart (making use of cheat sheets and visual organizers): i) 
story plot; ii) story setting; iii) characters; iv) EFL and storytelling; v) values and storytelling. An example of one of the learning centers can be seen in Figure 8 below. In this example, students had to listen to a lecture recorded by the teacher (about the way storytelling helps to introduce ethical values in the Primary classroom). Then they had to complete a think chart to record their findings. When each group had completed all the learning centers, the whole class shared and checked their answers. They were then ready to start drafting, designing, and creating their stories.

\section{FIGURE 8}

Task card and think chart for the learning center on "Storytelling and values" in English in Primary Education III. (Source: adapted from Clark, 2009a)
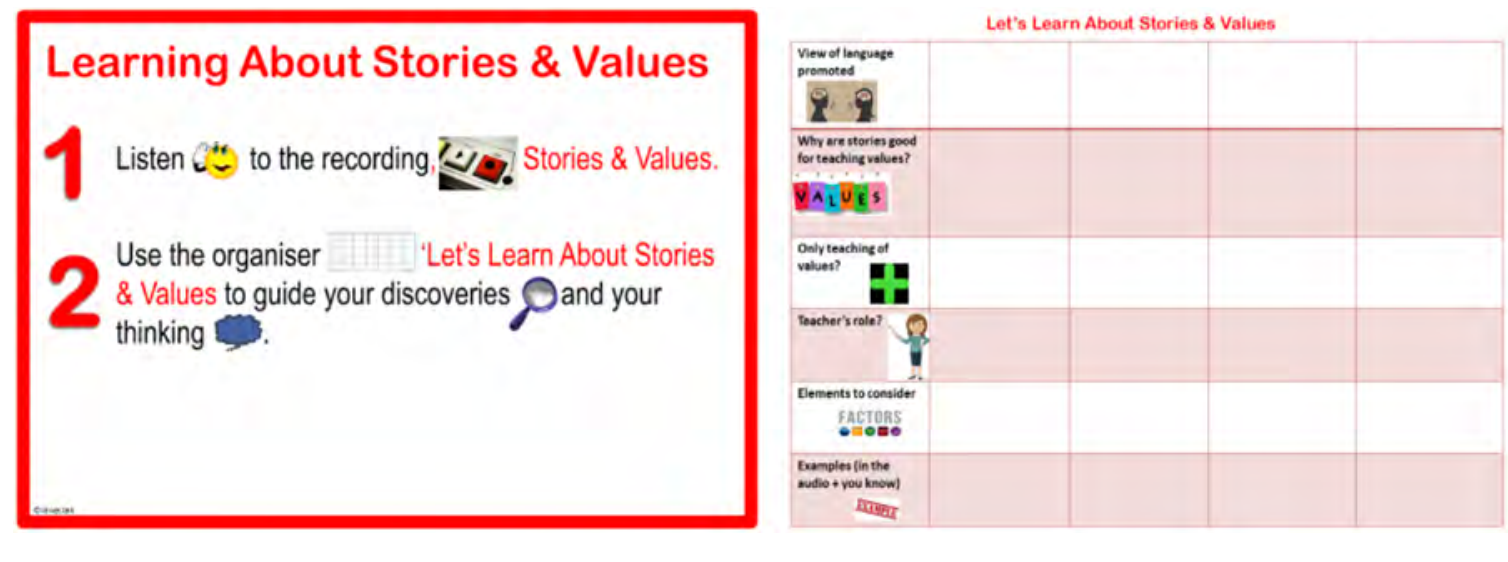

\section{Limitations of the proposal and/or future development}

Despite the fact that we believe that the proposal here presented responds to the main principles of CLT, TBI, and CELT, we also have to admit that a lot of reflection is needed in order for our students to focus their attention on language learning during the completion of their tasks and outcomes. As most of the tasks are open, we need to make them understand that it is not necessary for the teacher to control the process of learning, as happens in traditional, language-focused instruction. This means, in turn, that they need to realize that they are accountable for their own learning. This lack of control, which can be seen as a drawback of TBI, is also a challenge for teachers themselves. Besides, this is a long-term process that calls for a change in perspective from both students and teachers. To this end, collaborative team-teaching proves necessary, since this process is really time-consuming. Effective peer collaboration is paramount. Thus, it should be further institutionally promoted. Finally, we feel our professional development should include, among others, more specific knowledge and skills in the field of FL teaching and learning, further training on areas such as editing, copyright laws (e.g., to make use of Creative Commons licenses), graphic design (to make materials attractive), or ICTs. This means that we should carry on working to meet our students' professional needs and interests in their initial teacher training at university. 


\section{Conclusions}

Some positive remarks can also be made after the implementation of this proposal. First, we have identified general satisfaction, both on the students' and the teachers' part. As regards teachers' perceptions, we have realized that our teaching has become more meaningful and rewarding, since it contributes to our own and our students' professional development in a clear way. As we are teaching for specific students and purposes, by recognizing these needs and addressing them straightforwardly, our role as teachers has become more motivating and we can now identify what a context-sensitive pedagogy entails (Kumaravadivelu, 2001, 2006). As far as students are concerned, it is worth mentioning that, initially, this proposal did not meet their methodological expectations (Hedge, 2000), which were mainly language-focused. This is explained by the fact that, at this stage, they have been learning English through language-focused practices for many years, as well as the fact that society and educational authorities require competence level certificates. After instruction, they generally seem to feel that they are learning English in a more authentic and useful way, and they can see the relevance of the tasks carried out in class.

To conclude, it was our initial aim to offer a proposal to meet the challenge of teaching three EFL courses within the degree in Primary Education in our university context focusing on our students' development of their communicative competence and thinking skills as well as encouraging their reflection on their learning process, rendering such learning and thinking visible. We have based our proposal on key concepts and methodologies, and varied resources, materials, and techniques have been adapted and designed to meet our goal of offering an alternative syllabus model that goes beyond the notion of competence level as the target for FL learning in this education context. In this line, we hope to have shown that our proposal (i) revolves around topics that should be of professional interest to our undergraduate Education students; (ii) makes use of active methodologies, placing the learner at the center and promoting the use of language in a context and for a purpose (progressively through the three courses), and, above all, (iii) intends to provide a model of effective teaching for these Education students, so that they may consider these courses relevant in their initial teacher training. All in all, we consider that proposals like this imply an innovative path and the necessary steps to achieve a learner-centered and context-sensitive approach to the teaching and learning of FL in Higher Education.

\section{References}

AzmI, Noureddine, 2017: "The benefits of using ICT in the EFL classroom: From perceived utility to potential challenges", Journal of Education and Social Research 7 (1), 111-118.

BalL, Phil, 2016: "Using language(s) to develop subject competences in CLIL-based practice”, Pulso 39, 15-34. 
Ball, Phil, and Diana Lindsay, 2012: "Language demands and support for English-medium instruction in tertiary education. Reflection on the Basque experience" in Aintzane Doı, David LasagabAster, and Juan Manuel SierRa (eds.): English Medium Instruction at universities: Global Challenges, Bristol: Multilingual Matters, 44-64.

BentLey, Kay, 2010: The TKT Course: CLIL Module, Cambridge: Cambridge University Press.

BLAKE, Robert. J., 2008: Brave new digital classroom: Technology and Foreign Language Learning, Washington, DC: Georgetown University Press.

Brown, Douglas H., 2001: Teaching by principles: An interactive approach to language pedagogy, New York: Pearson Education.

Brown, Douglas H., 2002: "English language teaching in the post-method era: Toward better diagnosis, treatment and assessment" in Jack C. Richards and Willy A. Renandya (eds.): Methodology in language teaching, Cambridge: Cambridge University Press: 9-18.

Buck Institute for Education (BIE), 2003: Project Based Learning [https://www.bie.org/].

CEFR: Council of Europe, 2001: Common European Framework of Reference for Languages: Learning, Teaching, Assessment, Cambridge: Cambridge University Press.

CLARK, Lane, 2009a: Where thinking and learning meet, Victoria: Hawker Brownlow.

CLARK, Lane, 2009b: Where assessment meets thinking and learning, Victoria: Hawker Brownlow.

Chapelle, Carol, A., 2003: English language learning and technology, Amsterdam: John Benjamins Publishing.

Dörnyel, Zoltan, 1994: "Motivation and motivating in the foreign language classroom", The Modern Language Journal 78 (3), 273-284.

EluIs, Rod, 2003: Task-based language teaching and learning, Oxford: Oxford University Press.

EstalRe, Sheila, and Javier Zanón, 1994: Planning classwork: A task-based approach, Oxford: Heinemann.

EYLER, Janet, and Dwight E. GILES, 1999: Where is the learning in service learning?, San Francisco: Jossey Bass.

FInNEY, Denise, 2002: "The ELT curriculum: A flexible model for a changing world” in Jack C. RichARDs and Willy A. Renandya (eds.): Methodology in language teaching, Cambridge: Cambridge University Press, 69-79. 
Hedge, Tricia, 2000: Teaching and learning in the language classroom, Oxford: Oxford University Press.

Hedge, Tricia, 2005: Writing, Oxford: Oxford University Press.

Iannou-Georgiou, Sophie, and Pavlos Pavlou, 2003: Assessing young learners, Oxford: Oxford University Press.

Johnson, David W., and Roger T. Johnson, 2010: "Cooperative learning and conflict resolution: Essential skills in the 21st century" in William N. Bender (ed.), Project-Based Learning: Differentiating Instruction for the 21st century, Thousand Oaks, CA: Corwin: 59-63.

Kagan, Spencer, and Miguel KagAN, 1994: Cooperative learning, San Juan Capistrano, CA: Kagan Publishing.

Kumaravadivelu, Bala, 1992: "Macrostrategies for the second/foreign language teacher", Modern Language Journal 47, 12-21.

Kumaravadivelu, Bala, 2001: "Toward a postmethod pedagogy”, TESOL Quarterly 35, 537-560.

Kumaravadivelu, Bala, 2006: "TESOL methods: Changing tracks, challenging trends", TESOL Quarterly 40 (1), 59-81.

Lopes, Antonio, and Raúl RuIz-CECILIA, 2017: “Designing technology-mediated tasks for language teaching: A methodological framework”, H. U. Journal of Education 32 (2), 265-279.

Nessel, Denise, and J. G. Baltas, 2006: Thinking strategies for students' achievement, California, London, and New Delhi: SAGE Publications.

Papandreou, A. 1994: "An application of the projects approach to EFL", English Teaching Forum 32 (3), 41-42.

Pearse-Romera, Clara Rebecca, and Raúl Ruiz-Cecilia, 2019: "A Motivation Case Study of Students Learning English at a Secondary School in Granada, Spain", The International Journal of Interdisciplinary Educational Studies 14 (1), 31-45.

Project Zero Harvard. [http://www.pz.harvard.edu/]. Harvard: Graduate School of Education.

RichARDS, Jack C., and Theodore S. Rodgers, 2014: Approaches and Methods in Language Teaching, Cambridge: Cambridge University Press.

RitchHart, Ron, Marc Church, and Karin Morrison, 2011: Making thinking visible: How to promote engagement, understanding, and independence for all learners, SF: Jossey Bass. 
Scott, A. 2006: "Cooperative learning: Enhancing individual learning through positive group process", Annual Review of Nursing Education 6, 45-46.

SCRIVEnER, Jim, 2005: Learning teaching: A guidebook for English language teachers, London: Macmillan ELT.

SLavin, Robert E., 1980: “Cooperative Learning”, Review of Educational Research 50 (2), 315-342.

TRIBble, Chris, 1996: Writing, New York: Oxford University Press.

Wiluıs, Jane, 1996: A framework for task-based learning, London: Longman.

WiLLIS, Dave, and Jane WILLIS, 2007: Doing task-based teaching, Oxford: Oxford University Press.

Yazon, Jessamyn Marie O., Jolie A. Mayer-Smith, and Rosemary J. RedfieldB, 2002: "Does the medium change the message? The impact of a web-based genetics course on university students' perspectives on learning and teaching", Computers \& Education 38, 267-285. 